\title{
動物ゲノム情報を利用した遺伝子機能の解明
}

\author{
吉田健一 · 丸山公明
}

明治大学農学部生命科学科

\section{Elucidation of gene function based on the animal genomics}

\author{
Kenichi Yoshida and Kimiaki Maruyama \\ Department of Life Sciences, Faculty of Agriculture, Meiji University
}

\section{1.はじめに}

ヒト (International Human Genome Sequencing Consortium 2001)、マウス (Mouse Genome Sequencing Consortium 2002) およびラット (Rat Genome Sequencing Project Consortium 2004) でゲノム解読がほぼ完了した。 これは配列の判明というゲノム科学の第一段階に過ぎ ない。ポストゲノム戦略として、米国立ヒトゲノム解 析研究所 (NHGRI, NIH) のエンコード (ENCODE: Encyclopedia of Human DNA Elements) 計画や遺伝子ネ ットワークの解明を目指した国内外の取り組みから、 トランスクリプトーム、プロテオーム、メタボローム さらにはフェノーム (表現型の総体)という新しい概念 が次々に誕生した。ゲノム解読は単因子遺伝性疾患の 原因遺伝子の同定を容易にしただけでなく、一塩基多 型 (SNP: Single Nucleotide Polymorphism) 解析に代表さ れるようないわゆる“common diseases（生活習慣病に 代表される頻度の高い疾患)”の罹患性を規定する概念 すら生み出した (Miller と Kwok 2001; Shastry 2002)。 いまや高速シーケンサー（パイロシーケンシングなど） や高密度 SNP 連鎖不平衡マッピング（理論上、20 100 万のタグ SNPについて遺伝子型を判定すれば、全 ゲノムに存在する 1,000 万種類の一般的な SNPをカバ ーできる。全人類に対し、1\%以上の頻度で見られる 1,000 万の一般的な多型が人類の多型の $90 \%$ 以上を占 めている）により、個々人の全ゲノムを解析の対象と した多因子疾患（高血压、虚血性心疾患、癌、肥満、 糖尿病、喘息、精神疾患、偏頭痛、リウマチ様関節炎 などの “common diseases”は、複数の遺伝的要因と環 境要因の組み合わせが起因となる) 感受性遺伝子の同 定やオーダーメイド医療の実現さえ現実味を帯びつつ ある (Ross ら 2004)。実際は、個々のSNPが疾患に関 与する割合が極めて低いことが問題視されている。こ れを解決する目的で、多型の頻度と相互の関連性をゲ
ノムワイドに解析するための国際的な共同研究体が発 足している(The International HapMap Consortium 2003)。 一方、欧米の製薬企業は独自にこうした診断ツールの 開発を推進している。ゲノム・プロジェクトでは人類 共通の $99.9 \%$ 配列解読を目指した。一方、ハップマ ップ・プロジェクトでは個々人で異なる $0.1 \%$ 配列に おける共通なパターンの解明を目指している。

トランスクリプトームやプロテオームを構成するの は言うまでもなく遺伝子である。しかし、ゲノムプロ ジェクト開始当初の予想 (約 10 万個)に反してヒトの 遺伝子数は少なく、現在では 2 万から 2 万 5,000 個程 度と見積もられている (International Human Genome Sequencing Consortium 2004)。しかしながら、ゲノム プロジェクト以前から、特定の遺伝子座において判明 している突然変異の発生率とX 線誘発性突然変異の発 生数などから、哺乳類の遺伝子数は最大でも 3 万を超 えないであろうと予測されていた。このことからスプ ライシングによる mRNAの多様性と細胞系譜ごとの 時空間的な発現制御、クロマチン高次構造や DNA・ヒ ストンの修飾によるエピジェネティクス epigenetics、 さらには発現後の様々な翻訳後修飾とユビキチンによ るタンパク運命の決定が、細胞機能にとっていかに重 要であるか今や疑う余地はない。このような生体機能 情報の基盤である遺伝子をゲノム配列中で特定する 際、完全長 (full-length) cDNA プロジェクトが果たし た役割も見逃せない (The FANTOM Consortium and the RIKEN Genome Exploration Research Group Phase I \& II

連絡先: 吉田健一、明治大学農学部生命科学科 分子発生学研 究室 $\bar{T} 214-8571$ 神奈川県川崎市多摩区東三田 1-1-1

(e-mail: yoshida@isc.meiji.ac.jp) 
Team 2002)。ゲノムと完全長 cDNA あるいはEST (Expressed Sequence Tag) 情報があって始めて遺伝子発 現制御領域とコード領域に関する定義がなされ、細胞 のダイナミックな機能を理解し記述する上でフレーム ワークとなるオントロジーが定義されたのである (Camon ら 2003; Fraser と Marcotte 2004)。

本ミニレビューでは、ヒトや実験動物であるマウ ス・ラット以降解読されつつある動物ゲノム情報によ る比較ゲ)ム解析 (O’Brien 1999) が、遺伝子物理地図 作製やポジショナル・クローニングへの利用と並んで、 機能ゲノム学へいかに応用可能であるかについて述べ る。動物細胞 (ここでは哺乳類と鳥類を指す)の維持と 増殖にとって根源的な機構である細胞周期を構成する 因子が、動物ゲノムでいかに保存されているかが最近 の cDNA 解析を含むゲノム情報により明らかとなりつ つある。これら動物ゲノム情報を利用することで、こ れまでは容易に得られなかった遺伝学的解析材料がよ り簡便に作製される。言い換えれば、個体レベルでな く細胞レベルでのゲノム育種・改良の基本戦略を確立 する基盤が揃いつつある。動物細胞における重要な遗 伝子機能の解明が、今後さらに進展するであろう動物 ゲノム解析により加速する可能性について考察する。

\section{2. 動物ゲノム情報による遺伝子機能の予測}

\section{2-1. 細胞周期と DNA 複製開始制御機構}

動物ゲノム情報を活用した遺伝子機能予測に関して、 本章では細胞周期と DNA 複製開始を制御する遺伝子群 を例に考察する。2001 年ノーベル医学・生理学賞は、 細胞周期の基礎的メカニズム解明に対しであった。そ れは 1980 年代に Hartwell (1991) や Nurse (1994) が出芽 酵母 (いわゆるパン酵母) Saccharomyces cerevisiae や分 裂酵母 Schizosaccharomyces pombe の变異株から細胞周 期の基本因子を次々と同定した分子遺伝学的解析と、 Hunt（1989）によりウニ卵発生で変動するタンパク質と してサイクリン同定を可能とした生化学的解析が合流 した成果である。酵母は単細胞生物であるが、真核細 胞の代表として実験に頻用されてきた。これは世代時 間が短く、ゲノムサイズが小さいため、哺乳動物細胞 では考えられない単純さで分子遺伝学的・機能ゲノム 学的解析が可能であったためである。この様な潮流に 先立つ 1970 年代には、Masui と Markert（1971）による 両生類Xenopus での卵成熟の研究から MPF (M 期促進 因子) が同定されていた。その後の分子生物学の勃興 により、MPFの本体が実は Nurse らが酵母で同定した $\mathrm{Cdc} 2$ (CDK1) と Hunt が同定していたサイクリン B と
の複合体であったという事実が解明された。Cdc2 は プロテインキナーゼであり、このリン酸化活性をサイ クリンが調節タンパクとして、減数分裂だけでなく体 細胞を含むすべての動物細胞の分裂で制御している。

酵母から高等動物に至るまで細胞周期の制御メカニ ズムは、基本的な部分はよく保存されているが例外も ある。細胞周期エンジンのアクセルであるサイクリ ン/サイクリン依存性キナーゼ (CDK) 複合体には M (Mitosis) 期と S (Synthesis of DNA) 期で機能する分子 種がある。酵母では一種類の CDK に異なるサイクリ ンが結合する結果、 $\mathrm{M}$ 期と $\mathrm{S}$ 期が区別される。一方、 ヒトを含む哺乳動物では複数種の CDK が存在する。 $\mathrm{CDK} 1$ は M 期で、CDK2 は S 期で、さらに $\mathrm{G} 0-\mathrm{G} 1$ 移行 期では CDK4，6が重要な役割を果たす。これら CDK はそれぞれ複合体を形成するサイクリンがある。 $\mathrm{CDK} 1$ はサイクリンA または B と、CDK2 はサイクリ ン A またはEと、CDK4/6 はサイクリン D と結合する。 細胞周期エンジンのブレーキに関しても酵母に対して 動物細胞では多くの遺伝子の存在が確認されている。 癌抑制遺伝子 p 5 3 の下流に位置し、サイクリン E/CDK2 インヒビターである $\mathrm{p} 21^{\mathrm{Waf} 1 / \mathrm{Cip} 1}$ やそのファミ リー遺伝子 $\mathrm{p} 27^{\mathrm{Kip} 1 、 サ イ ク リ ン ~ D / C D K 4, ~} 6$ インヒビ 夕ーである $\mathrm{p} 16^{\mathrm{INK} 4 \mathrm{a}}$ や $\mathrm{p} 19^{\mathrm{ARF}}$ など、それらの多くで 発現制御あるいは遺伝子そのものの異常が何らかの形 で細胞の異常増殖に関与している (Sherr とRoberts 1999）。この様に同じ真核生物であっても、醅母を代 表とする単細胞生物と比較すれば、哺乳類などの多細 胞生物における細胞周期制御機構の複雑性 (complexity) と重複性 (redundancy) は際立っている。

細胞周期を秩序立てて進行させるのに重要な局面と して、G1-S 移行期が注目されている(BellとDutta 2002）。特に S 期は DNA が複製される時期であり、 $\mathrm{S}$ 期でのみ一回限りの複製開始を許諾するライセンシン グ機構は G1 期に準備される (Chong ら 1996)。サイク リン $/ \mathrm{CDK}$ 複合体以外で、このような重要なイベン トに関与する遺伝子群として ORC (Origin Recognition Complex) 1-6、MCM (Minichromosome Maintenance) 2-7、 CDC (Cell Division Cycle) 6、CDT1、Geminin、CDC7、 MCM10、TopBP1 および CDC45 な゙が知られている。 これらの $\mathrm{G} 1$ 期特異的な遺伝子発現は、主として転写 因子 E2Fファミリーにより制御されている (Dyson 1998; Yoshida と Inoue 2004a; Yoshida と Inoue 2004b)。転写因子 E2F1-4 は普段、癌抑制遺伝子 pRb (Retinoblastoma Protein) と結合することで不活化され ている。しかし、一端サイクリン / CDK 複合体によ 
り $\mathrm{pRb}$ がリン酸化されると結合を脱し、転写因子とし ての機能を発揮する（Harbour ら 1999）（図 1）。発現後 これら遺伝子群は、染色体に散在するオリジンに秩序 正しく結合あるいは接近し、DNA 複製開始のシグナ ルとなる (図 2)。この結果、細胞周期は制御点を通過 し再び $\mathrm{S}$ 期から $\mathrm{G} 1$ 期に逆行することはない。この様 な制御が破綻すれば異常な DNA 複製が惹起され、ゲ ノムは安定性を失うと共に細胞はアポトーシスあるい は癌化へと至る（Sherr 1996）。

以上述べた重要な遺伝子群の構造について、ヒトと マウス・ラットとの比較がこれまで主であった。動物 ゲノム解析の進展により、チンパンジーやイヌ、鳥類 であるニワトリとの比較解析が最近可能である。

\section{2ー2. 遺伝子コード領域の比較解析}

ヒトとマウスの比較ゲノム解析から新たに発見され た遺伝子は、マウスゲノム解読時、ヒトで約 1,200 個、 マウスで約 9,000 個に達した。哺乳類では 2004 年 7 月、 Lindblad-Toh 率いるチームによりイヌ (Boxer, Canis familiaris) ゲノムの概要版 (ドラフト) が公開された。 ゲノムサイズはヒト・マウスの約 30 億塩基対に対し、 約 25 億塩基対であった。ヒトとイヌの配列比較では、 全体で $25 \%$ 以上が共通していた。また、現在わかっ ているヒトの遺伝子約 24,500 個のうち、約 18,500 個 (約 $75 \%$ ) がイヌにも存在していた。これらヒトとイ ヌに共通する遺伝子のほとんどがマウスにも存在して おり、哺乳類に共通する遺伝子であると考えられる。 常染色体数 $(2 n)$ はヒト、マウスおよびイヌでそれぞれ、

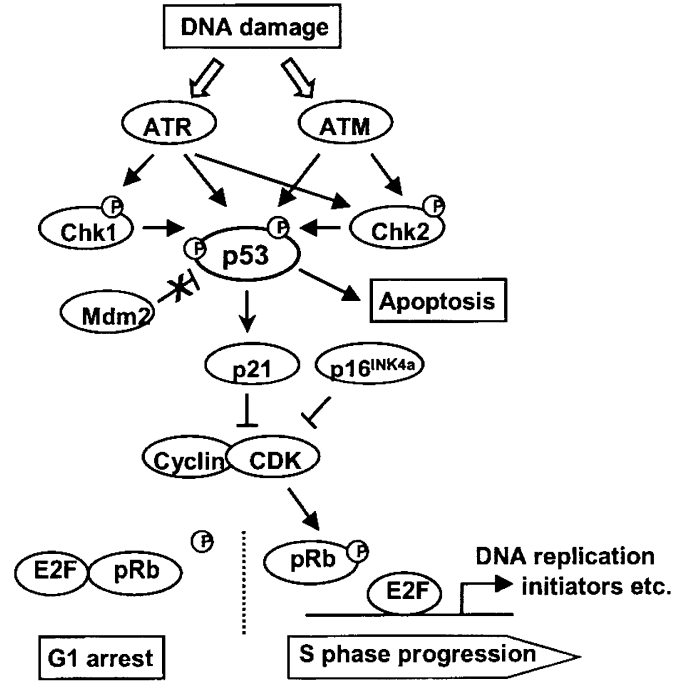

図 1. 紐胞周期 G1-S 移行制御とほぼすべての癌に関与 する p53および pRb 経路との関係。

紫外線や放射線、化学薬剂などによる細胞 (DNA) ダメージは、センサーキナーゼ（ATRおよび ATM）を誘導し、Chk1、Chk2 あるいは p53をリ ン酸化する。p53はリン酸化されると、MDM2に よる分解を逃れ細胞内に安定的に存在する。p53 は標的遺伝子 p21の転写を活性化する。p21や p16は練胞周期エンジンのブレーキであり、CDK のキナーゼ活性を抑制する。抑制された CDKは pRbをリン酸化できない。結果、転写因子 E2F は pRb と結合したままとなり、標的遺伝子の転写を 活性化できず細胞周期は G1 期に停止する。この 間に、細胞は損傷 DNA の修復を実行する。一端、 損傷が回復すると CDKにより pRbはリン酸化さ れ、E2F は標的遺伝子の転写を活性化する。標的 遺伝子には細胞周期 $S$ 期進行に必須の DNA 複製 開始因子群などが含まれる。修復が果たされない 程の強いDNA ダメージを細胞が受けた場合、p53 はアポトーシス関連遺伝子の転写を増強させ、細 胞死へと至る。

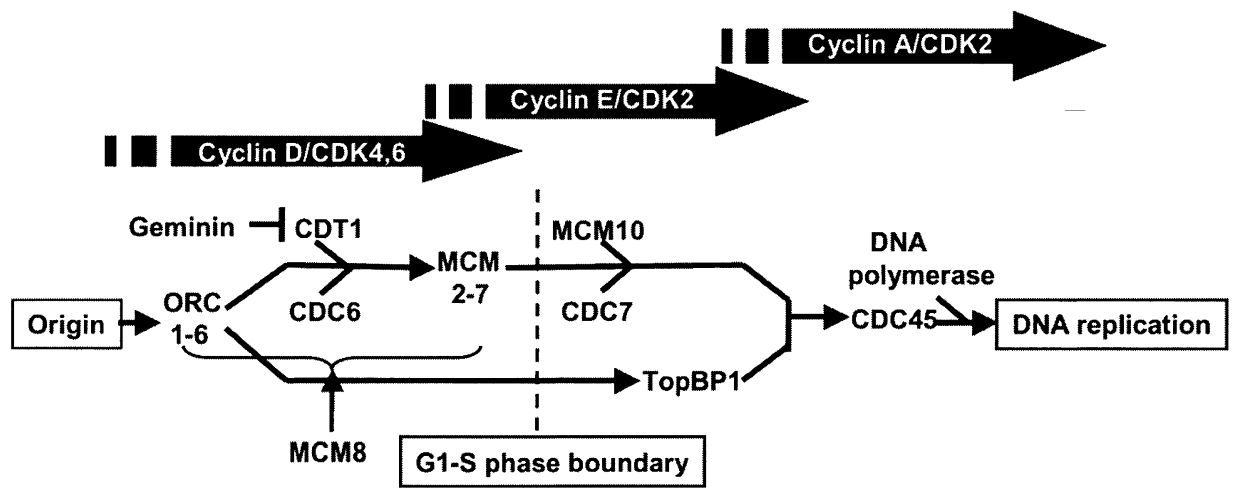

図 2. 細胞周期 G1-S 移行期での染色体オリジンにおけるDNA 複製開始および制御因子。

ORC1-6がまずオリジンに結合し、CDT1とCDC6が MCM2-7 のクロマチン・ローディングを促進する。 MCM2-7によりオリジン二本鎖 DNA は一本鎖となる。Geminin は M-G1 期以外で、CDT1に結合することで、 CDT1 の機能を阻害する。MCM10 と TopBP1 は、それぞれ別経路でCDC45のオリジン会合を助ける。CDC45 はDNA ポリメラーゼのローディング促進因子である。細胞周期特異的サイクリン・CDKおよび CDC7 はキナー ゼ活性で、DNA 複製開始および制御因子をリン酸化する。MCM8 は MCM2-7 と直接複合体を形成するという報

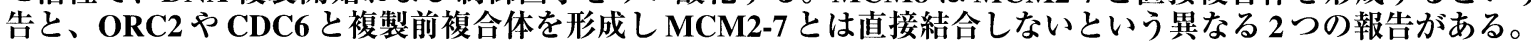


22、38 および 36 と異なるが、染色体間の構造類似性 (シンテニー) は保存されている。イヌでは 400 以上の 遺伝病が知られており、ヒト以外では全ての動物中で 最も多い (OMIA, NCBI, NIH)。ヒトの疾患の殆どは、 イヌにそれに対応する病気がある。乫然深い眠りに陷 るナルコレプシー Narcolepsy と呼ばれる睡眠異常のイ ヌモデルがその一例である。また、イヌはげっ歯類よ り体の大きさ、生活ぶりや寿命もヒトに近い。詳細な
イヌゲノムが解読されれば、マウスの時と同様に遺伝 子の探索が加速されるだろう。一方、家畜ではニワト リに関してESTが集積されていた。しかし、公開され てはいなかった (Abdrakhmanov ら 2000; Boardman ら 2002）。2004 年 11 月、ニワトリゲノム解析により約 10 億塩基対の DNA 情報を含むドラフトが公開された (International Chicken Genome Sequencing Consortium 2004）。同時に、大量の EST および 2,000 個以上の完

表 1. 紐胞周期および DNA 複製開始を制御する主用な遺伝子群のヒト・マウス・ラット・イヌ・ニワトリ間におけるアミ 八酸相同性比較。

ヒトを 100 とした相対值で表示 $(\%)$ 。 ND は同定されていない遺伝子。右側にヒトのアミノ酸長 (aa) を表示。

\begin{tabular}{|c|c|c|c|c|c|c|}
\hline & Human & Mouse & Rat & Dog & Chicken & \\
\hline Cyclin A1 & 100 & 84 & 84 & 88 & 69 & 465 \\
\hline Cyclin A2 & 100 & 89 & 89 & 91 & 71 & 432 \\
\hline Cyclin B2 & 100 & 89 & 90 & 93 & 71 & 398 \\
\hline Cyclin D1 & 100 & 94 & 93 & 94 & 87 & 295 \\
\hline Cyclin E1 & 100 & 79 & 77 & 83 & 75 & 410 \\
\hline CDK4 & 100 & 88 & 88 & 97 & ND & 303 \\
\hline CDK6 & 100 & 96 & 97 & 97 & 91 & 326 \\
\hline p27Kip1 & 100 & 88 & 87 & 90 & 69 & 198 \\
\hline $\mathrm{pRb}$ & 100 & 90 & 89 & 93 & 76 & 928 \\
\hline $\mathrm{E} 2 \mathrm{~F} 1$ & 100 & 86 & 86 & 93 & 64 & 437 \\
\hline ORC1 & 100 & 69 & 71 & 84 & 55 & 861 \\
\hline ORC2 & 100 & 79 & 78 & 92 & 69 & 577 \\
\hline ORC3 & 100 & 80 & 82 & 89 & 67 & 712 \\
\hline ORC4 & 100 & 90 & 90 & 94 & 75 & 436 \\
\hline ORC5 & 100 & 94 & 89 & ND & 84 & 435 \\
\hline ORC6 & 100 & 78 & 74 & 87 & 57 & 252 \\
\hline MCM2 & 100 & 96 & 96 & 94 & 90 & 904 \\
\hline MCM3 & 100 & 94 & 94 & 97 & 83 & 808 \\
\hline MCM4 & 100 & 95 & 95 & 94 & 90 & 863 \\
\hline MCM5 & 100 & 95 & 95 & ND & 88 & 734 \\
\hline MCM6 & 100 & 96 & 96 & 98 & 88 & 821 \\
\hline MCM7 & 100 & 93 & 94 & 96 & ND & 719 \\
\hline MCM8 & 100 & 90 & 90 & 93 & 79 & 840 \\
\hline MCM10 & 100 & 78 & 77 & 83 & 71 & 874 \\
\hline CDC6 & 100 & 81 & 81 & 89 & ND & 560 \\
\hline $\mathrm{CDC} 7$ & 100 & 81 & 81 & 90 & 68 & 574 \\
\hline $\mathrm{CDC} 45$ & 100 & 92 & 91 & 90 & 82 & 566 \\
\hline TopBP1 & 100 & 77 & 77 & 91 & 68 & 1435 \\
\hline CDT1 & 100 & 76 & 75 & 71 & 53 & 546 \\
\hline Gemini & 100 & 79 & 77 & 78 & 55 & 209 \\
\hline
\end{tabular}


全長 cDNA 配列の報告が相次いだ（Hubbard ら 2004； Caldwell ら 2005)。

DNA 複製開始を制御する遺伝子群は、多くの動物 でも普遍的であろうと考えられている。しかしながら、 これまでヒトとマウス・ラットでの実験的比較解析が 主であり、他種のオーソログ (ortholog: 進化上保存さ れている遺伝子セット)について詳細は不明であった。 ヒト・マウス・ラット・イヌおよびニワトリを含む動物 間について、Blast algorism (Altschulら 1997; http://www.ncbi.nlm.nih.gov; HomoloGene) により遺伝子 コード領域を比較解析した。結果、DNA 複製開始因 子を含む 30 個の細胞周期調節遺伝子で極めて高いア ミノ酸レベルでの相同性が認められた (表 1)。これら の遺伝子において、相同性の平均はヒトを 100 とした 場合、マウス 86.5、ラット86.1、イヌ 90.3、ニワトリ
73.9 であった。ORC 遺伝子群 (ORC1-6) と比較して MCM ヘリケースファミリー (MCM2-7) はより高い種 間の相同性を見せた。これは ORCが認識するオリジ ン配列は、酵母で同定されている複製開始点と比べ、 高等動物では配列の特異性が低いブロードな領域であ るためであろう。一方、染色体オリジン近傍でATP 依存的な DNA二本鎖巻き戻しに関与する $\mathrm{MCM} ヘ リ$ ケースファミリーでは、高い特異性、即ち立体構造の 保存が要求されると考えられる。新しいMCMヘリケ ースファミリー遺伝子として最近同定された MCM8 は、複製前複合体に参加すると報告されている (Maiorano ら 2005；Volkening と Hoffmann 2005)。実 際、種間のアミノ酸相同性比較でも他の MCM 同様、 コード領域全域にわたって高い相同性を示した（図 3)。 一部アミノ酸が明らかなウシ MCM8（XM_597511およ

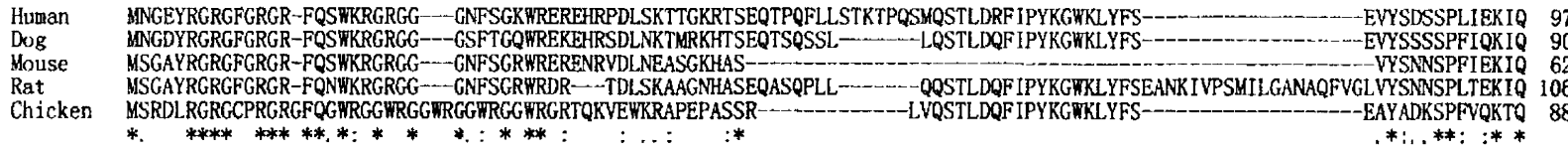

Human AFEKFFTRHIDLYDKDEIERKGSILVDFKELTECGEVTNLIPDIATELRDAPEKTLACMGLAIHQVLTKDLERHAARLQAQEGLSNDGETYVNVPHIHARVYNYEPLTQLKNVRANYYGK 217 Dog AFENFFTRRIDLYDKDEIERKGSILVDFKEL TEDNEMADL VPNIANELRDTPEKTLACMGLAIHQVLTRDLERHAAEL QAQEGFSRDGET WVNVPHIHARVYNYEPLTHLKNVRANYYGK 210 Mouse AFEKFFTRHIDLYDKDEIERKGSILVDFKEL TKADEITNL IPDIENALRDAPEKTLACMGLAIHQVLTKDLERHAAELQAQEGLSNGGETMVVPHIYARVYNYEPLTHLKNIRATCYGK 182 Rat AFEKFFTRHIDLYDKDEIERKGSILVDFKELTKDNEITNL IPDIENALRDAPEKTLACMGLAIHOVLTKDLERHAAELQAQEGLCNGGGTMVNPHIYARVYNYEPLTHLKNIRATCYGK 226 Chicken AFEKFFMQRIELYDKDEIERKGSILVDYKELIEDRELTKSIPNISTELRDMPQKILQCHGLAIHQVLTKDLERHAAELQVQEGLPLDGEPI INVPLIHARLYNYEPLTQLIKNVRANCYGK 208

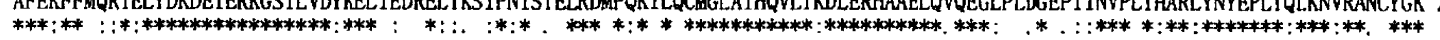

Human YIALRGTWRVSNIKPLCTKMAFLCAACGEIQSFPLPDGKYSLPTKCPVPVCRGRSFTALRSSPLTVTMDWQSIKIQELMSDDQREAGRIPRTIECELVHDLVDSCVPGDTVTITGIVKV 337 Dog YIALRGTVVRVSNIKPLCTKMAFLCAACCEVQSFSLPDGKYNLPTKCPVPTCRGRSFTALRNSPLTVTWDWOSIKIQELJSDDQREAGRIPRTIECELVHDLVDSCVPGDTVTITGVVKV 330 Mouse YISIRGTVRVSNIKPLCTNMAFQCAACGEIQSFPLPDGKYTLPTKCPVPACRGRSFAPLRSSPLTVTLDWQLIKIQELLISDAQREAGRIPRTIECELVHDLVDSCVPGDTVTVTGIVKV 302 Rat YISIRGTVVVVNIKPLCTKMAFOCAACGEIOSFPLPDGKYMLPTKCPVPACRGRSFTPLRSSPLTVTMDWOLIKIOELMSDAQREAGRIPRTIECEL VHDL VDSCVPGDTVTVTGIVKV 346 Chicken YIALRGTVRVSNIKPLCTKLAFVCGTCGDVQSVPLPDGKYTLPTKCLVPECRGRSFTPDRSSPLTATVDWOSVKVQELASDDQREAGRIPRT IECELVQDLVDSCVPGDVVTITGVVKV 328

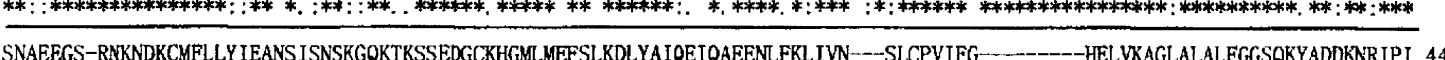
Human SNAEEGS-RNKNDKCMFLLYIEANSISNSKGQKTKSSEDGCKHGMLMEFSLKDLYAIQEIQAEENLFKLIVN--SLCPVIFG---D---HELVKAGLALALFGGSQKYADDKNRIPI 444 Dog SNAEEGS-RNKNDKCMFLLY IEANSVSNSKGQKTKTSEDGCKHGALMEFSLKDLYAIQEIQAEENLFRLIWN---SLCPVIFG--D----HEL.VKAGLALALFGGSQKYADDKNRIPI 437

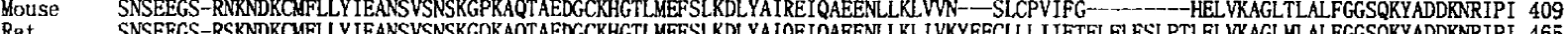

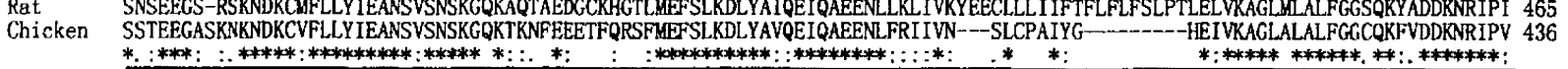

Human RGDPHILVVGDPGLGKSOMLOAACNVAPBGVYVCGNTTTTSGLTVTL SKDSSSGDFALEAGAL YLGDOGICGIDEFDKMGNOHOALLFAYEOOSIST AKAGVYCSLPAPTSIIAAUTYG 564 Dag $\quad$ RGDPHVLVVGDPLGKSQMLQAVCNVAPRGVYVGNTTTTSGLTVTLSKDSSSGDFALEAGALVLGDOGICGIDEFDKMGNOHQALLEAMEOOSISLAKAGMVSLPARTSIIAAANPVG 557 Mouse RGDPHVLIVGDPGLGKSQMLQAACNVAPRGVYVGNTTTSSGLTVTLSKDSSSGDFALEAGALVLGDQGICGIDEFDKMGNQHQALLEAMEQQS ISLAKAGVVCSLPARTSI IAAANPVG 529 Rat $\quad$ RGDPHVLIVGDPGLGKSOMLQAACNVAPRGVYVGNTATSSGLTVTLSKDSSSGDFALEAGALVLGDQGICGIDEFDKMGNQHQALLEAMEQQS ISLAKAGVVCSLPARTSI IAAANPVG 585 Chicken RGDPHVLIVGDPGLGRSQMLQAVCNVAPRGVYVCGNTSTSSGLTVTLSRDGASGDFALEAGALVLGDOGICGIDEFDKMGSQHQALLEAMEQQSISLAKAGIVCSLPARTSIVAAANPVG 556

Human GHYNKAKTVSENLKMGSALLSRFDLVFILLDTPNEHHDHLLSEHVIAIRAGKQRTISSATVARKNSQDSNTSVLEVVSEKPLSERLKVYPGET IDPIPHQLLRKY IGYARQYVYPRLSTE 684 Dog GHYNKAKTVSENL MGSSALLSRFDLVFILLDTPNEDHDHLLSEHVIAIRAGKQRTVSSATIARMNSQOSNTSVLEVVSDKPLSERLKVVPGET IDLIPHQLLRKY IGYARQYVYPRLSTE G? Mouse GHYNKARTVSENLKMGSALLSRFDLVFILLDTPNEOHDHLLSEHVIAIRAGKOKAVSSATVTRVLSQDSNTSVLEVVSEKPLSERLKVAPGEQTDPIPHOLLRKYIGYAROYVHPRLSTD 649 Rat GHYNKARTVSENLKMGSALLSRFDLVFILLDTPNEQHDHLLSEHVIAIRAGKORAVSSATVSRVZSQDSNTSVLEVVSEKPLSERLIKVAPGEKTDPIPHOLLRKYIGYAROYVYPRISTE 705

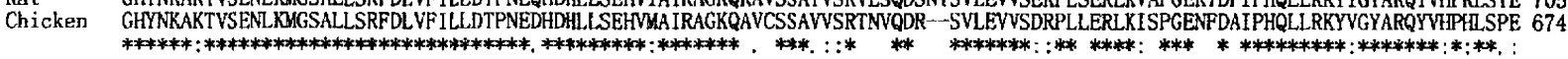

Humen AARYLQDFYLELRKQSQRLNSSPITTRQLESLIRLTEARARLELREEATKEDAEDIVEIMKYSMLGTYSDEFGNLDFERSQHGSGMSNRSTAKRFISALNNVAERTYNNIFQFHQLRQIA 804 DUg AAQILQDFYLELRKQSQRLNSSPITTRQLESLIRLTEARARLELREEATKEDAEDIVEVMKYSHLGTYSDEFGKL,DPERSQHGSGMSNRSTAKRFISALNNIAERTYNNLFQFQQLRQIA 797 Mouse AAQALQDFYLELRKQSQRVGSSPITTRQLESLIRLTEARARLELREEATREDAEDI IEIMKHSMLGTYSDEFGNLDFERSQHGSGMSNRSTAKRFISALNS IAERT YYNIFQYHQLRQIA 769 Rat AAQALQDFYLELRKQSQRVGSSPITTRQLESLIRLTEARARLELREEATKEDAEDI IEIMGKHSMLGTYSDEFGNLDFERSQHGSGMISNRSTAKRF ISAL.NSIAERTYNNIFQFHQLRQIA 82 5

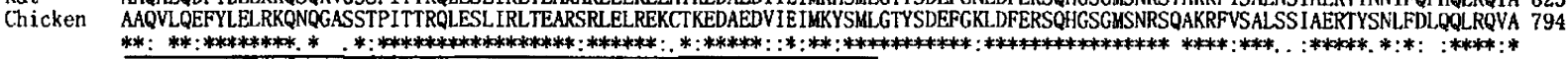

HUman KELNTQVADFENFIGSLNDQGYLLKKGPKVYQLOTM 840

Dog KELNIQVVDFENFIGSLNDQGYLLKKGPKVYQLQTM 833

Mouse KELNIQVADFENFIGSLNDQGYLLKKGPKIYQLQTM 805

Rat. KELNIQVADFENFIGSLNDQGYLLKKGPKIYQLQTM 861

Chicken KELQIRVFDFESFIESINDOGYLLKKGSRLYQLQTY 830

図 3. ClustalWによるヒト・イヌ・マウス・ラット・ニワトリMCM8のアミノ酸アラインメント。 種間で保存されたアミノ酸部位を下段に示す（）。下線部は、MCMファミリー2-7で保存された MCM2/3/5 family domain を示す。 
びXM_584128) とヒトMCM8 との相同性は 89\% (113292 アミノ酸) および95\% (409-840アミノ酸)に達し た。一方、免疫系に重要な遺伝子の内、インターロイ キン IL-6、10、12 $\beta$ および 17 について同様の解析を実 施した結果、ヒトを 100 とした場合、マウス 61.0、ラ ット 61.3、イヌ71.3、ニワトリ 44.8 であった。また、 これら 4 つのヒト遺伝子の平均遺伝子コード長は 220 アミノ酸であった。インターロイキン受容体遺伝子で も、インターロイキンと同様の結果であった。平均遺 伝子コード領域がインターロイキンより 2 倍以上長い にも関わらず、細胞周期調節遺伝子群 (ヒト遺伝子で 平均遺伝子コード長は597アミノ酸) が種間を超えて 見せる高い相同性は、これら遺伝子群が細胞機能にと っていかに重要であるかを示す。このような複数の動 物間において、多くの遺伝子の相同性比較が可能にな ったのは動物ゲノム解析の成果である。これら以外で も、内分泌系を制御するホルモンおよびその受容体、 細胞内シグナル伝達系を構成するキナーゼなど、動物 間での相同性は極めて高い。

米国立ヒトゲノム解析研究所は 2004 年 8 月、ゾウ やオランウータンなどの貴重な動物を含む、さらに 18 の生物のゲノム解析を推進すると発表している。近い 将来、解析が進行しているウシ、ブタ、ヒッジやネコ の配列情報と併せて、精度の高い比較ゲノム解析が可 能となろう。これにより、さらに多角的なアミノ酸比 較解析が可能となり、遺伝子の保存性から機能の重要 性を類推できるようになろう。

\section{2-3. 発現制御領域の比較解析}

動物ゲノム情報で遺伝子コード領域のみならず、発 現調節領域の解析からも遺伝子機能の保存性と重要性 が検証可能である。実際、ヒトとマウスではゲノムの イントロン領域でも約 $2.5 \%$ が共通している。各遺伝 子の機能を調整するうえで何か重要な役割を担ってい る可能性が高い領域である。他方、複数種ゲノムの比 較解析ではこの様な共通した領域のみならず、種間の 多様性を生み出すような特徽的な配列の同定も期待さ れる。具体例として、智の遺伝子探索と嗅覚に関する 遺伝子について以下に紹介する。

ヒトとチンパンジーのゲノムを比較することで、ヒ トがヒトであるための智の遺伝子領域を探索しようと いう GEMINI プロジェクト (GSC, RIKEN) が進行して いる。高度に発達した認知機能、直立歩行、複雑な言 語の使用などの、人間に特異的な能力獲得に関係した 遺伝的変異は何であるかを解明するためには、ヒトと
チンパンジーのゲノムの比較が不可欠である。22 番染 色体比較の結果、ヒトとチンパンジーの間には、 $1.44 \%$ \%塩基置換と約 68,000 力所に扔ける塩基の挿 入や久損が存在した (The International Chimpanzee Chromosome 22 Consortium 2004)。比較した遺伝子 (231 個) のうち、83\%の遺伝子でアミノ酸配列が異な っていた。挿入や欠損の頻度やこれらが生じている領 域の広さは従来予想以上に大きかった。22 番染色体 は、チンパンジーゲノム全体のわずか $1 \%$ に過ぎない。 したがってゲノム全体で言えば、ヒトとチンパンジー で有意差のある遺伝子の数は数千個に達する可能性す らある。ゴリラなど、他の大型類人猿のゲノム配列と の比較が待たれる。アミノ酸コードの差異が、実際、 タンパク質レベルでどれくらい細胞機能に影響するか は今後の重要な課題であろう。さらに、ゲノムの比較 解析から、遺伝子が発現する夕イミングと発現量を規 定する配列の同定も重要である。実際、ヒトとチンパ ンジーで比較された遺伝子の約 $20 \%$ において、発現 パターンに有意差が見られた。ヒトとチンパンジーが 500 万年前に共通の祖先から分かれて以来、双方の遺 伝情報に起きた変化、特にゲノムに取り込まれたレト ロトランスポゾン (ゲノム中に多数存在する、数百塩 基程度を単位とする繰り返し配列) が遺伝子発現に及 ぼす影響も無視できないだろう。セレラ社 (Celera Genomics）が短期間でヒトゲノム解読を達成した全ゲ ノムショットガン (WGS) 方式 (Venterら 1996)では、 この様な繰り返し配列（従来は junk DNA と称されてい た）は見落とされがちであった。

2004 年度ノーベル医学・生理学賞が、比い受容体遺 伝子 (嗅覚受容体：olfactory (odorant) receptor) の発見 と嗅覚メカニズムを解明したコロンビア大学の Dr. Richard Axel とフレッド・ハッチントン癌研究所の Dr. Linda Buckに贈られたのは記憶に新しい (Buck と Axel 1991）。嗅覚受容体は 7 回膜貫通型に特徵付けられる 最大の遺伝子ファミリーで、特異的な転写制御がある。 また、匂い識別以外にも軸索投射にも関わっていると いう知見だけでも、基礎生物学的には非常に魅力的で ある。嗅覚は人間でこそ退化しているが、他の生物で は一番重要な感覚であり、この仕組みの全貌を解明す ることは、生物そのものを理解することにつながると いっても過言ではない。ヒトゲノムプロジェクトの結 果、ヒト化い受容体遺伝子は約 1,000 個あることが明 らかにされた。しかし、多くは機能していない偽遺伝 子 (pseudogene) であり、実際は約 350 個と推定されて いる。このような機能遺伝子の同定には、他の動物ゲ 
ノムとの比較解析 (特にエクソン・イントロン構造の比 較による intron-less paralog の確認) が重要な役割を果 たした (Zozulya ら 2001)。興味樑い事に、嗅覚があま りよくないといわれるニワトリのゲノムにも、朼い受 容体遺伝子が約 200 個存在した。一方、イヌやマウス は、ヒトやニワトリょり鋭い嗅覚を有するものの、遺 伝子数にさほど差はない。生理学的な差異を理解する ためには、アミノ酸コード情報だけでなく、遺伝子発 現領域を含めたゲノム構造の比較解析が重要であろ う。嗅覚系に抢ける“1匂いセンサー(嗅細胞)、1 受 容体”ルールが保証されるためには、それぞれの細胞 において、正の制御 DNA 領域による匂い受容体遺伝 子の活性化と共に、活性化された化い受容体遺伝子に よる残りすべての匂い受容体遺伝子活性抑制のメカニ ズム (negative feedback) を理解する必要がある。これ はホルモンとその受容体による内分泌系の制御でも同 様である。動物間での体格の違いや、種に特徽的な生 理・薬理反応を理解するには、遺伝子発現のオンとオ フを制御する cis 配列の同定が遺伝子コード領域同定 後の急務である。将来的にはプロテオミクス解析によ り、cis 配列に結合する trans 因子の同定とそれらが構 成する転写因子複合体の全容解明が必要であろう。こ の様に、アミノ酸コード領域のみならず、遺伝子発現 調節領域の比較解析が動物種間格差を理解する上で今 後益々重要であろう。

ヒト・マウス・ラット・イヌおよびニワトリの MCM8 全長 cDNA あるいは遺伝子コード領域で Blast 検索し、 MCM8 ゲノム中のプロモーターと予測される配列を比 較解析した。それぞれのコンティグ contig あるいは BACクローンの GenBank Accession Numberは、ヒト (AL035461)、マウス（AL929562）、ラット $\left(\mathrm{NW}_{-}\right.$047658)、イヌ $\left(\mathrm{NW}_{-}\right.$139896)、ニワトリ （NW_060324）である。いくつかの動物に扔いて、 MCM8 の転写開始点は決定されていない。そこで翻訳 開始コドン ATG を含む現時点でエクソン 1 と考えら れる周辺領域の配列を、転写因子結合予測ソフトウェ ア TRANSFAC (Knuppel ら 1994) で解析した (図 4)。 結果、ヒト・マウス・ラットおよびイヌで、転写因子 E2F 結合配列 (consensus; 5'-TTTCGCGC-3') と CCAAT 配列が予測された。CCAAT 配列結合因子の一

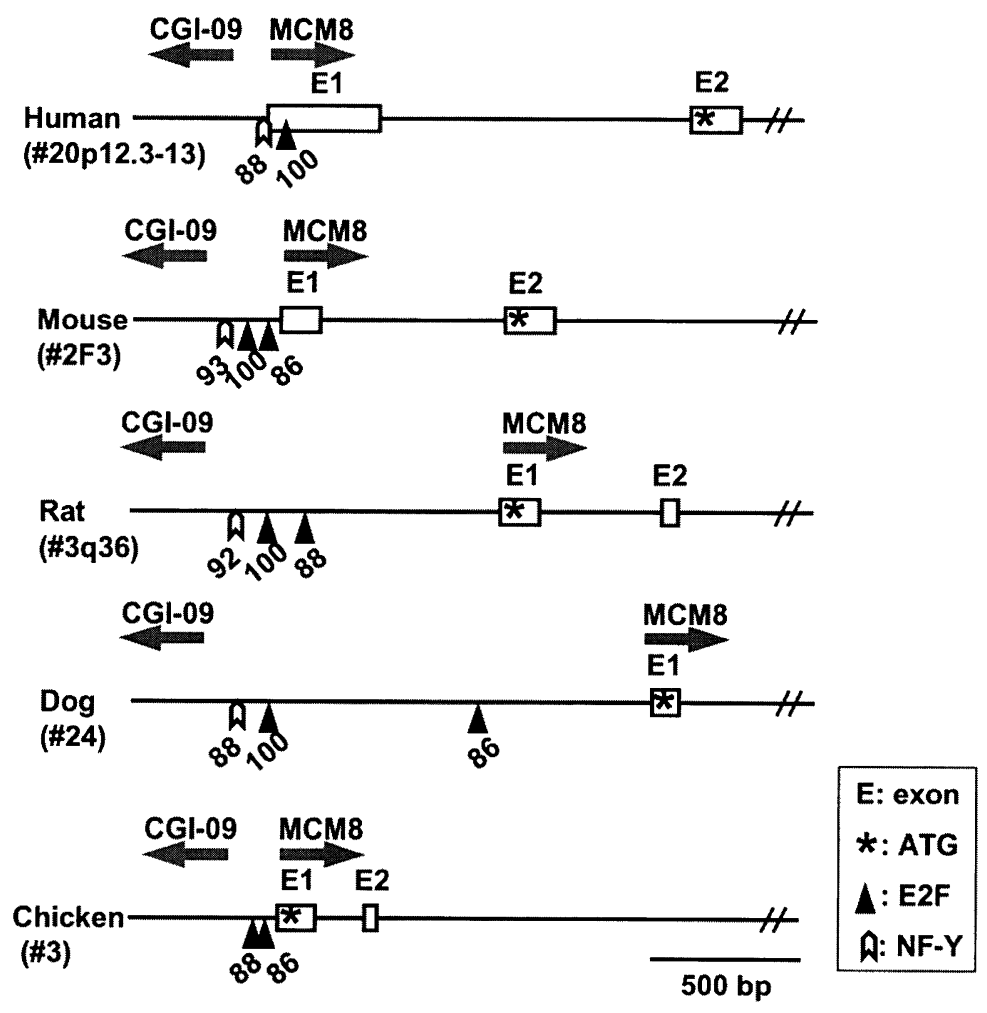

図 4. ヒト・マウス・ラット・イヌ・ニワトリMCM8の予想されるプロモーター領域。

転写因子 E2F およびNF-Y (CCAAT 配列) 結合部位と TRANSFAC スコア (最大值 100 に対する相対值)を下段に 表示。それぞれの染色体上の位置と、MCM8 遺伝子の近傍で逆向きに位置する CGI-09 遺伝子を図示。ラット・ イヌおよびニワトリでは、翻訳開始コドンATGが暫定的な転写開始点である。 
つとして転写因子 NF-Y がある。NF-Y は MHC 主要組 織適合性遺伝子複合体クラス II の発現に必須な因子と して知られている (Boss 1997)。また、NF-Yは高等動 物で様々な遺伝子の発現調節に関与する。しかし、転 写因子 E2F と比較して、細胞周期 G1-S 移行に重要で はない。一方で、転写活性化に㗢くE2F1-3が、NF-Y の結合したCCAAT 配列を介して、G2/M 特異的な遺 伝子発現を制御すると報告されている (Zhu 2004)。二 ワトリでは CCAAT 配列を確認できず、一方で E2F 結 合配列は存在した。ヒトと鳥類は約 3 億 1,000 万年前 に共通の祖先から分かれたと考えられている。哺乳類、 鳥類を問わず、MCM8 のプロモーター予想領域に E2F 結合配列が保存されている事実は、E2Fによる MCM8 発現制御が特に G1-S 移行期において普遍的に重要で ある事を示唆する。これら in silico 情報は、将来リポ ーターアッセイなどで検証されなければならない。し かし、このような動物ゲノムの比較解析から、MCM8 が他の MCM2-7 同様、G1-S 移行期で DNA 複製開始制 御に関与していると予想できる。G1-S 移行期以外で も、細胞周期では $\mathrm{G} 2 / \mathrm{M}$ 期に発現上昇を示す重要な遺 伝子群が同定されている。この様な遺伝子プロモータ ーでは、CDE/CHR (cell-cycle-dependent element/cell cycle gene homology region) と称される配列が種間を超 えて保存されている(Yoshida 2005a)。このように、ア ミノ酸レベルでの高い保存性だけでなく、発現制御領 域の配列比較解析からも遺伝子機能は推測でき、細胞 内での遺伝子機能同定へ向けたその後の実験デザイン を容易にする。

上述した様なアプローチをヒト、マウス、ラットお よびイヌの全ゲノムに対し比較解析した結果が報告さ れている(Xieら 2005)。種間において保存されたプロ モーター配列から、174 個のモチーフが同定された。 注目すべきことに、プロモーター領域のみならず 3’非 翻訳領域 (3'-UTR) でも106 個のモチーフが同定され た。この領域を介したマイクロ RNA（miRNA; noncoding RNAの一部)による転写後発現調節 (翻訳阻害) は、ヒト遺伝子の約 $20 \%$ に及ぶと推察される。 miRNA は一般に 19-23 塩基の短い非コードRNA であ り、標的 mRNA の 3'-UTR に結合する。 miRNA と並 んで、RNAi (RNA 干渉：RNA interference)に関与する siRNA (small interfering RNA) が注目されている (Sontheimer 2005; Matzke と Birchler 2005)。特に 2001 年、マックスプランク研究所の Dr. Tuschl が HeLa な どのヒト細胞で、21 塩基の二本鎖 siRNAにより標的 遺伝子の発現抑制に成功して以来、RNAi は分子生物
学実験に欠かせない手技となった（Elbashir ら 2005）。 miRNA が内在遺伝子の発現調節のための抑制システ ムであるのに対し、siRNA は外来遺伝子に対応するた めの抑制システムである。例えば、ウイルスが細胞の タンパク質製造装置を乗っ取ってウイルス自身のタン パク質を作り出そうとするときなどに siRNA は始動す る。最近、この様な small RNA world に新しい役者が 加わった。 smRNA（small modulatory RNA）と名付けら れた新しいクラスの small RNA は二本鎖を形成し、夕 ンパク質と相互作用（転写因子が本来結合する DNA と 拮抗）することで、これまで知られている siRNAや miRNA（翻訳レベルでの遺伝子発現制御）と異なり、 転写レベルで遺伝子発現を制御する（Kuwabaraら 2004)。

以下に miRNA と siRNA との生成過程を簡単に紹介 する。 miRNA は 1,000 塩基程度の長い RNAの一部と して転写される。まず核内で二本鎖 RNA に特異的な リボヌクレアーゼ Droshaによって、70〜 100 塩基の ヘアピン RNAに分解される。このへアピン RNA は transportin-5 を介して細胞質に移動し、二本鎖 RNA 特 異的リボヌクレアーゼDicerによって切断される。こ の切断によりできた 19 ～ 23 塩基の miRNA は、RNAi に関与している RISC (RNA-Induced Silencing Complex) に類似した複合体に結合する。動物の場合、複合体に 結合した一本鎖 miRNA が、mRNAに結合する。 miRNA は mRNA に対して完全一致ではなく部分的に 相補的な配列になっている。即ち、miRNAの 5, 端と、 適切な長さの、対形成していない塩基の中間部に位置 するミスマッチやポリヌクレオチドのバルジ(膨らみ) の間にみられる相同性が、遺伝子サイレンシングの程 度に影響を及ぼす最重要因子であると言われる (Kiriakidou ら 2004)。この様な miRNA とその認識部 位 (MRE) との部分的な配列一致の許諾は、まさにプ ロモーター配列に対する転写因子の結合性と同じであ る。いずれにしても、既知 miRNA の多くの標的は同 定されておらず、標的の選択と標的との結合に関する 規則性も多くは不明である。一方、RNAiでは細胞に 取り込まれた長い二本鎖 RNA（dsRNA）が、細胞内で Dicerにより短い $21 〜 25$ 塩基の siRNAに切断される。 siRNA はRISC を構成しているタンパク質と共に、 RISCに取り达まれ、取り込まれた二本鎖 SiRNA はほ どけて一本鎖となる。活性化された RISC は、siRNA のアンチセンス鎖と mRNA 間の塩基対相互作用によ り、完全に相補的な転写物に結合する。RISCが結合 した mRNA は切断され、配列特異的な mRNAの分解 
により、ジーンサイレンシング (遺伝子の発現抑制) が 起こる。つまり、miRNA はRNAiのように mRNAの 分解には関与せず、miRNAが結合した mRNA は翻訳 されないままでいるため、対応する遺伝子の発現量が 低下する。線虫 Caenorhabditis elegans において lin-4、 let-7 と称される最初の miRNA が発生のタイミングを 制御すると報告された (Pasquinelli と Ruvkun 2002)。 その後、数百種類の miRNA が線虫、ショウジョウバ エDrosophila、マウス、ヒト (200-250個と概算されて いる)で確認されている。 miRNA レベルは組織間と発 生過程で違っている。また、いくつかの miRNAが、 初期発生 (Reinhart 5 2000)、細胞増殖と細胞死 (Brennecke ら 2003)、アポトーシスと脂肪代謝 (Xu ら 2003）を含む様々なプロセスに影響することが報告さ れている。さらに、 miRNA と癌の関連も報告されて いる(Calin ら 2002)。動物細胞に抢ける遺伝子発現を 制御する転写因子のように、miRNAも生物種間で保 存され重要であると推測される。

以上より、動物ゲノムの比較解析から浮き彫りにさ れる配列相同性や特異性は、遺伝子の時空間的な発現 制御に関する情報をもたらし、遺伝子機能を解析する 上で不可欠である。しかしながら、個々の遺伝子・遺 伝子産物の機能を調節している機構の数は多い。例え ば、クロマチン構造の開放の程度とそれに伴う転写活 性は、ヒストンとDNAの酵素的な修飾に関与する蛋 白質複合体によって制御されている。この様な事象は、 cis 配列の同定やゲノム比較解析だけでは到底理解で きない。次章では、動物ゲノム情報から遺伝子機能を 理解するための細胞アッセイ系構築について述べる。

\section{3. 遺伝子破壊による動物細胞での機能解析}

\section{3-1. 背景}

家畜ゲノム解析は、有用遺伝子を探索するのが主目 的である。ウシやブタ、ニワトリなどでは、ヒト、マ ウスなどのゲノム解析が進んでいる生物との比較地図 作製へ向けた研究が取り組まれてきた（Edwards 1994；

Womack と Kata 1995）。家畜個体において、ある形質 に関連する遺伝領域を調べる方法として、連鎖解析 (質的な形質) P QTL (quantitative trait loci) 解析 (量的 な形質)がある。これらを利用して、ウシなどで数々 の遺伝疾患関連領域や有用形質関連領域が発見されて いる (Rocha ら 2002；Grisart ら 2002)。最終的には原 因遺伝子が同定され、塩基配列やアミノ酸配列から遺 伝子の機能を推測し、実際の形質への関わりが解明さ れる。この様な代表例として、Belgian Blue と
Piedmontese 家系のダブルマッスル (double-muscling) 責任遺伝子同定が挙げられる。同定された遺伝子は TGF $\beta$ スーパーファミリーに属する Myostatin と命名さ れた分泌タンパクで、Belgian BlueではC 末端の $11 \mathrm{bp}$ 欠損によるフレームシフトが機能ドメインの欠損を招 いた。Piedmonteseでも Belgian Blue 変異が検出された 同領域内に存在するシステインのチロシン変換が筋肉 過形成を引き起こした (Grobet ら 1997; Kambadur ら 1997; McPherron と Lee 1997)。

この様な解析手法 (Forward Genetics) に対して、遺 伝子情報から個体での表現型を直接解明しょうとする Reverse Geneticsがある。現状でこの様な遺伝子機能の 解析法はノックアウトマウス作製である (Yoshida ら 2001）。実際、Myostatin の生物学的な意義の解明でも、 遺伝子同定後のノックアウトマウス作製による機能解 析が果たした役割は大きい(McPherron と Lee 2002)。 今日では動物ゲノム情報の解析から新規遺伝子を発見 し、バイオインフォマティクス Bioinformatics でお抒 よその機能予測が可能である。それは既存の遺伝子あ るいは種間との相同性、または何らかのモチーフ構造 を Blastp、PROSITE あるいはPfam などのアルゴリズ ムでin silico 解析することから始まる(Yoshida 2005b)。 さらに創薬のターゲットになるかなどを検証するに は、発見した遺伝子について生細胞レベルでの機能解 析が必須である。この様なニーズがノックアウトマウ ス作製を含めた Reverse Genetics の原動力となってき た。疾病に関わる遺伝子では、その約 $90 \%$ \%゙ヒトと マウスで同じであり、マウスの実験動物としての価值 は依然大きい (Smithies 1993)。遺伝子機能の解析は、 ノックアウトマウス作製に頼るのが現状である。しか し、研究に使用されるマウスの数は、年間 2,500万匹 以上にのぼると見られ、倫理的な問題も提起されてい る。マウス肧性幹 (ES：Embryonic Stem) 細胞における 標的遺伝子の遺伝子破壞後、マウス個体でのへテロお よびホモマウス作製に要する時間は長く、維持に要す るコスト面でも効率が悪い。生体機能に重要な遺伝子 をマウスで破壊し、それらから初代細胞を得ることで 化合物のスクリーニングに使用する試みもある。しか し、個体由来の初代培養細胞はいろいろな系列の細胞 が混在している上に、増殖能が限られているので、細 胞内の現象を解析することが困難である。

マウスの代替モデルとして、魚が注目されている。 脊椎動物の主要な系統はいずれも魚型の動物であり、 その一つがヒトを含む四肢動物となっている。今から 4 億 5,000 万年前の古生代に生きていた、ヒトと魚類 
に共通する祖先のゲノムの構造が解明された。フグの 一種であるミドリフグ (Tetraodon nigroviridis) の遺伝 子マップ作製とヒトとの比較ゲノム解析から、新たに 900 個近くのヒト遺伝子が明らかとなった (Jaillonら 2004)。ミドリフグのゲノムサイズは知られている氽 椎動物中、最も小さく約 3 億塩基対である。いわゆる ジャンク DNA が少なく、ヒト遺伝子の大半に対応す るものが、ミドリフグゲノムには2つずつ存在する。 この様な全ゲノム重複は魚の特徵であり、そのことが 進化に有利に作用してきたと言えよう。さらに、小型 硬骨魚類であるゼブラフィッシュ (Danio rerio) やメダ カ (Oryzias latipes) のゲノム解読も 21 世紀に入り急速 に進行している。これらは、大量の個体数を比較的容 易に維持できるため、大規模突然変異作成の系として 優れている。また、マウスではできない大規模スクリ ーニングが可能で、開発した薬剤の影響も容易に発生 段階の遺伝子発現パターンを指標として観察できる。 ゲノム情報を活用した新しい薬剤開発系と言える。特

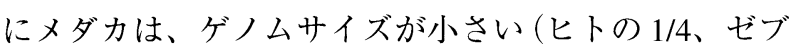
ラフィッシュの 1/2)、多型に富む近交系が存在する、 性染色体が確定している、温度感受性変異体の単離が 容易であるなどのメリットがある。変異体の中には、 メダカに特有なものからヒト疾患モデルとなるものま で多様である。また、メダカは環境変異原・内分泌擋 乱物質のモニターとして有効である。メダカにおけ る変異体作製は、変異誘発剂かゲノムへのトランス ポゾン挿入によるランダムミュータジェネシスによ る。そして、形態変化を生ずるような変異体につい て、破壊された遺伝子を同定する。従って、目的の 遺伝子機能をピンポイントで解析するには問題があ る。また、必ずしもすべての研究室で汎用できるモ デル動物ではない。

遺伝子産物の機能解析をどのように行うかは、従来 の生化学解析による再構成実験や、単離した遺伝子を 細胞に導入し発現させるのが一般的である。しかし、 多くの種類の遺伝子とそれらが関与する生化学反応の 解析はしばしば困難である。また、トランスジーンの 強発現では、生理反応以上の効果 (pleiotropic effect)を 検出してしまう可能性がある。これらの欠点を補完す るアッセイ法として、標的遺伝子産物のみを阻害する インヒビターや中和抗体が考えられるがこれとて万能 ではない。最近では、動物細胞でも前述したRNA干 渉による簡便なノックダウンが主流となりつつある。 しかし、抗ウイルス応答 (インターフェロン様反応)の 惹起や非特異的な抑制、さらには抑制効果の程度を制
御できないなど、未だ解決すべき問題は多い (Huppi ら 2005)。これに対して、体細胞を直接の出発材料と し、内在性遺伝子をゲノムレベルで改変することで遺 伝子機能を解析するメリットは計り知れない。様々な 実験手法の問題点を解決する手法として、体細胞を 出発材料とした標的相同組み換えによる遺伝子破壊 法を紹介する。最近、動物ゲノム情報を有効に利用 することで、マウス ES 細胞以外の株化された体細胞 で遺伝子破壊が実施されている。特にニワトリDT40 細胞とヒト体細胞を用いた取り組みについて現状を 紹介する。

\section{3ー2. ニワトリ DT40 細胞}

ニワトリ B リンパ球由来 DT40細胞は、Avian leukosis virus (ALV) 感染により樹立されたニワトリB 細胞腫 (Baba ら 1985) で細胞バンクから入手可能であ る (RCB1464、RIKEN)。ニワトリDT40細胞で遺伝子 破壊を企図する際、従来はマウスでのノックアウトマ ウス作製がそうであったように標的とする遺伝子近傍 のゲノム配列情報が必要であった。これはゲノムライ ブラリーのスクリーニングと塩基配列決定といった面 倒なプロセスを意味する。しかし最近、ニワトリゲノ ムおよびcDNA 情報が急増しこの問題は解決されつつ ある。

標的組み換えは、導入したDNA コンストラクトが それと相同な塩基配列を持った染色体DNA との間で 相同組み換えすることによって起こる。この原理はノ ックアウトマウス作製におけるマウス ES 細胞での相 同組み換えと同様である (Smithies ら 1985; Mansour ら 1988）。マウス ES 細胞での相同組み換え効率は、 組み換え標的部位の構造に依存し、約 $5 \%$ 前後と言わ れる。ニワトリDT40 細胞を使用するメリットとして、 この様な組み換え効率が高い事があげられる (Buerstedde と Takeda 1991; Arakawa H と Buerstedde 2004）。それ以外でも細胞の生存に必須である遺伝子 をノックアウトする際は、レスキューシステムにより 遺伝子発現のオン・オフが可能 (Wang ら 1996)、CreLoxP システムによるマーカーリサイクルとコンディ ショナル・ノックアウトが可能 (Arakawa ら 2001)、ネ オマイシン (G418) やハイグロマイシン、ピューロマ イシンなどの薬剤耐性マーカーの組み合わせにより同 一細胞内で複数個の遺伝子を破壊可能、などが挙げら れる。これらに加えて、変異遺伝子を有するDT40 細 胞がカタログ化されWeb (http://pheasant.gsf.de/ DEPARTMENT/dt40.html) 上で検索できる (Buerstedde 
ら 2002)。また、トランスクリプトーム解析が進み DT40 細胞による多角的な機能解析が見达める (Wahl ら 2004）など、枚挙にいとまがない。

欠点として、DT40 細胞はアウトブレッドのニワト リ由来なので対立遺伝子間で多くの多型が存在する。 したがって、ノックアウトコンストラクトDNA と染 色体 DNA との間のミスマッチで標的組み換え効率が 大きく低下する可能性がある。これはへテロ接合体 (+/-) 細胞の (+) アレルより再度ノックアウトコンスト ラクトDNAを作成し直す必要が生ずることを意味す る。しかし、この久点も最近明らかにされた 280 万ヶ 所にも及ぶニワトリ 3 系統 (食肉用のブロイラー、食卵 用のレイヤー、ウコッケイ) と原種 (キジ目キジ科) で ある赤色野鶏 (Red Jungle Fowl、Gallus gallus) との SNP 情報を活用する事で解決されるだろう（International Chicken Polymorphism Map Consortium 2004)。

ニワトリでは、遺伝子の機能解析に有用な DT40 細 胞の開発と実験的困難さを軽減させるに足るゲノム情 報の充実が相乗効果を示した好例である。歴史的に見 ても、ニワトリは胚成長モデルとして発生生物学で重 用されてきた。DT40細胞における遺伝子破壊株のカ タログ化も徐々に進行しており、ポストゲノム解析に おける遺伝子機能解明へ向けた一つのモデルを提示し ている(Brown ら 2003)。

\section{3-3，上卜体細胞}

マウスを用いた遺伝学的解析は近交系で行われてい る。ノックアウトマウス作製では主に $129 \mathrm{~Sv}$ 由来 ES 細胞が用いられ、この際全く同一の (isogenic) DNAを 用いることが標的相同組み換え成功の鍵と言われる (te Riele ら 1992)。ノックアウトマウスの代替として、 ヒト細胞での遺伝子破壊法は重要である。特に個体 での初期発生といった生理機能ではなく、細胞周期 など細胞増殖の根幹を成すようなメカニズムの解析 にはヒト細胞が最適である（Brownら 1997）。しかし、 ヒトは実験動物と異なりへテロな集団である。約 $500-1,000 \mathrm{bp}$ に一ヶ所の多型が存在する (Wang ら 1998)。

ヒト体細胞での標的相同組み換えを目指した研究 は、約 10 年前に始まった。予想に反して不死化され ていない繊維芽細胞を始め、多くの癌由来細胞で nonisogenic DNA でも標的相同組み換えが成功している （Hanson と Sedivy 1995）。癌抑制遺伝子 p53では、異 なる 4 種類のヒト細胞で G418 をクローン選択に使用 した標的相同組み換え実験が行われた。その効率 (相
同組み換え体 $/ \mathrm{G} 418$ 耐性非相同組み換え体) は、ヒ ト大腸癌細胞 HCT116 (1/600)、ヒトリンパ芽球 TK6 (1/120)、ヒト胚由来皮膚繊維芽細胞 LL1 (1/87)、ヒト 胚由来肺繊維芽細胞 LF1（4/33）であった（Bunzら 1998；Sedivyら 1999）。p53の標的遺伝子である p21 Waf1/Cip1 では、HCT116 (37/100)、LF1 (3/20)、ヒト 大腸癌細胞 DLD-1 (5/157) であった。G418 選択による ヘテロ細胞同定後、ハイグロマイシン選択下での同一 ベクターDNAによる(+)アレルの相同組み換えでも ほぼ一致した組み換え効率が得られた（Waldman ら 1995；Polyak ら 1996；Brown ら 1997)。HCT116 細胞 ではミスマッチ修復系が欠損しており、それが isogenic DNAを要求しないのではという理由から初期 の実験に多用された。しかし、現在では多くのヒト細 胞でisogenic DNAを要求しない事実が確認されてい る。HCT116細胞は ATCC (CCL-247) から入手可能で ある。

p53 下流に位置する p21 Waf1/Cip1 の細胞内機能解析を 巡っては、Leder 研究室 (Harvard Medeical School) による ノックアウトマウス作製 (Deng ら 1995) と、Vogelstein 研究公 (Johns Hopkins University) での HCT116 細胞に おける遺伝子破壊株（Waldman ら 1995）の作製競争が 演じられた。その後も HCT116細胞を用い、14-3-3 $\sigma$ (Chan ら 1994)、Securin (Jallepalli ら 2001)、DNA methyltransferase (Rhee ら 2002)、 $\beta$ カテニン (Chan ら 2002)、CDC4 (Rajagopalan ら 2004) を始めとした重要 な遺伝子がノックアウトされ、細胞周期やゲノム安定 性、シグナル伝達機構の詳細なメカニズム解明に貢献 している。以上から、ヒト体細胞での遺伝子破壊は十 分実験ベースにかなう。我々は、HCT116細胞におい て、DNA 複製開始因子である ORC2、Geminin および MCM7 の機能ドメインを含むエクソンのみを相同組み 換えにより破壊する事に成功した（図 5)。相同組み換 え効率を高めるため、薬剤選択マーカーであるネオマ イシン耐性遺伝子にはプロモーターを与えず、標的遺 伝子部位に正確に組み达まれた時にのみ発現させる工 夫を加えた (プロモーター選択)。通常、HCT116 細胞 は G418 濃度 $400 \mu \mathrm{g} / \mathrm{ml}$ で一週間培養すると死滅する。 ネオマイシン耐性遺伝子が非相同領域にランダムに組 み込まれた細胞でも、偶然に近傍のプロモーターで G418 耐性となる場合がある。しかし、G418 濃度を $1,000 \sim 5,000 \mu \mathrm{g} / \mathrm{ml}$ にすることで、多くの非相同組み 換え体は死滅し、相同組み換え体同定の効率は上昇し た。この様な技術的改良の結果、ヒト体細胞での遺伝 子破壊効率はニワトリDT40 細胞となんら遜色がな 


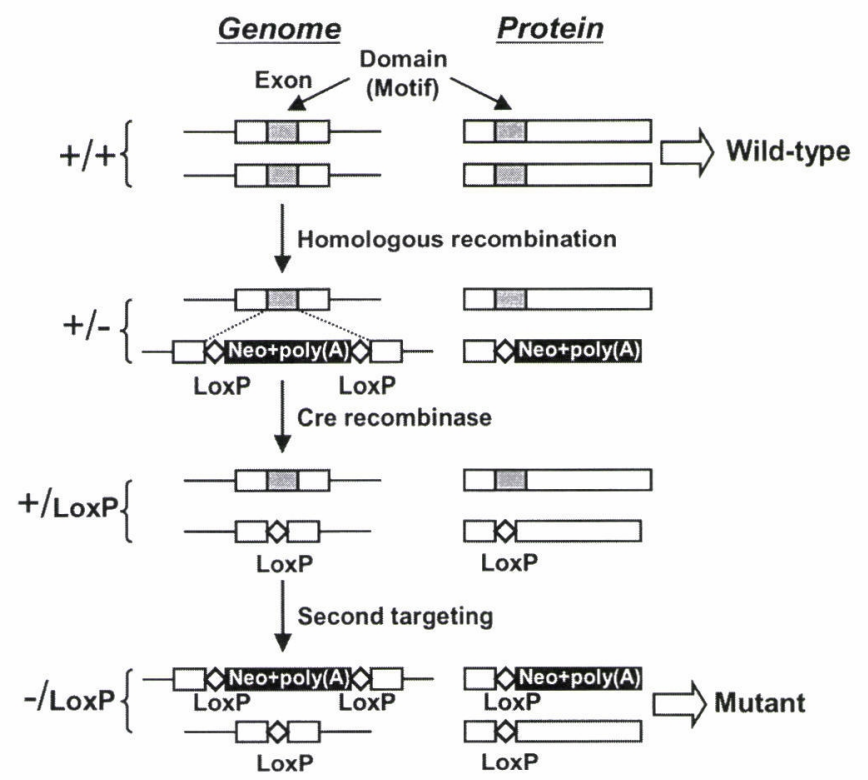

図 5. ドメイン・ノックアウト HCT116 細胞作製のフロー・チャート。

標的ヒト遺伝子の機能ドメイン(灰色で表示)を相同組み換えにより、ターゲティング・ベクターと置換する $(+/-)$ 。 (-)アレルより発現されるタンパクは、ドメインより前の N 末端領域とネオマイシン耐性遺伝子 (Neo) との融合夕 ンパクである。次に、CreリコンビナーゼによりLoxP配列で挟まれたネオマイシン $($ Neo $)$ と poly $(\mathrm{A})$ を取り除く。 バクテリオファージP1 由来の配列特異的組換え酵素 Cre は特異的組換え配列 LoxP を認識する。LoxP 配列は 34bp と長いため，偶然この配列と一致した配列がゲノムに存在することは無い。一個の LoxP 配列はゲノム上に 残るが、LoxP前後でタンパクの読み枠は合致する(+/LoxP)。従って、（LoxP）アレルより発現するタンパクはド メイン領域のみ失ったタンパクである。2 回目の相同組み換えで、残った正常アレルをノックアウトする。この 結果、片方のアレルのみから変異タンパクが産生される。変異タンパクは、ドメイン領域以外は正常夕ンパクと 変わらない。野生型 $(+/+)$ 細胞と変異細胞 $(-/$ LoxP $)$ を比較解析することで、標的遺伝子の機能ドメインに関する 情報が得られる。

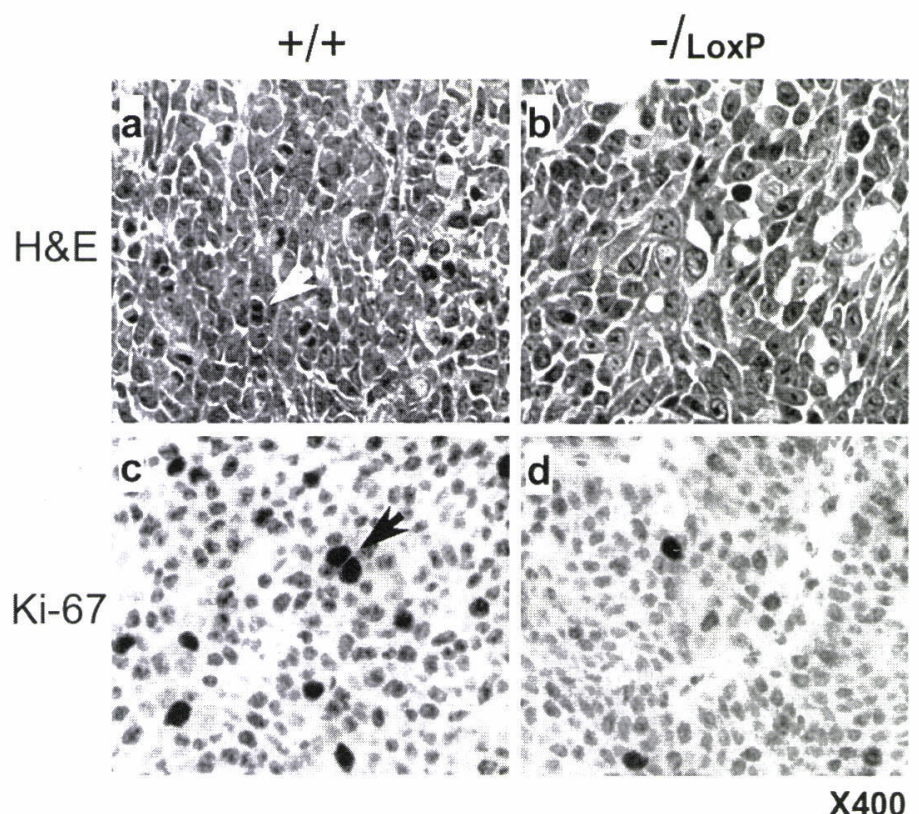

図 6. Gemininのユビキチンリガーゼ APC/C 認識配列 destruction box ノックアウト HCT116 紐胞における細胞周期異常。 野生型細胞 (+/+; a, c) と変異細胞 (-/LoxP; b, d) をヌードマウス皮下に移植後 (4 週間)、ヘマトキシリン・エオジ ン染色 (H\&E; a, b) および細胞增殖マーカー Ki-67による免疫組織染色 $(\mathbf{c}, \mathbf{d})$ を施し鏡検 $(400$ 倍)。+/+ 細胞で明 瞭に観察された紼胞分裂像 (a で白矢印、 $\mathrm{c}$ で黒矢印) は、ー/LoxP 紼胞で有意に減少した。 
い。変異細胞株を用いた一連の解析から、DNA 複製 開始因子による細胞周期 G1-S 移行のメカニズムと癌 化との関連を解明した (Dhar とYoshida ら 2001； Yoshida と Inoue 2003; Yoshida ら 2004)。Geminin の工 ビキチンリガーゼ APC/C (Anaphase Promoting Complex/Cyclosome) 認識部位である破壊ボックス Destruction box を相同組み換えでノックアウトした細 胞 (-/LoxP) では、野生型細胞で明瞭に確認された細 胞分裂像が減少した (図 6)。ユビキチン・プロテアソ 一ム経路では、ユビキチン活性化酵素、ユビキチン結 合酵素、ユビキチンリガーゼにより、76個のアミノ酸 よりなるユビキチンが基質タンパク質のリジン残基に 共有結合される。反応は繰り返され、基質はマルチユ ビキチン化される(モノユビキチン化の場合もある)。 ユビキチン化されたタンパク質は $26 \mathrm{~S}$ プロテアソーム により特異的に認識され、分解される。ユビキチンリ ガーゼは、どのタンパク質をいつ、どこでユビキチン 化し、いかにプロテオソームに搬入するかという重要 な役割を担う。この様なタンパク質の分解反応に関与 するユビキチンの研究に対して 2004 年度のノーベル 化学賞が授与された。ユビキチン化については、G1/S 期で働く SCF (Skp1/Cullin/F-box) 並びに Mdm2（p53を 分解)、および $\mathrm{G} 2 / \mathrm{M}$ で働く $\mathrm{APC} / \mathrm{C}$ 各複合体がよく知 られている。実際、それらによって細胞周期エンジン を調節する各期特異的サイクリンの運命も支配されて いる。Geminin 以外でも、サイクリン A、B、およびD、 CDC6、Securin で Destruction box の存在が知られてい る(Page と Hieter 1999; Castro ら 2005)。Geminin が $\mathrm{APC} / \mathrm{C}$ にり M 期特異的にタンパク分解される結果、 $\mathrm{Cdt} 1$ は開放され $\mathrm{G} 1$ 期に複製前複合体の形成を可能と させる。-/LoxP 細胞では、細胞周期を通じて Geminin が常に安定的に存在する結果、Cdt1 ひいては MCM ファミリーによる複製前複合体の形成を部分的 に阻害し、細胞の増殖と癌化を抑制した。ユビキチ ン機能異常と癌化との関連が注目されているが、 Geminin は抗癌剤の分子標的の一つとして興味深い遺 伝子と言える。

HCT116 細胞は癌由来細胞としては珍しく、カリオ タイプが正常細胞とほぼ同等 (diploid) で、維持しやす い。我々の研究目標の一つは、この様なヒト細胞株で 効率的な遺伝子破壊技術の精度を高め、ゲノム情報に より同定される新規遺伝子の機能を生細胞で解明する ことである。この様な遺伝子破壊細胞株をカタログ化 することで、以下に挙げる 5 つの研究が展開可能であ る。1）遺伝子破壊により生ずる遺伝子ネットワークを
システムとして解析できる。即ち、標的遺伝子が単一 のシグナル伝達に関与するのか、あるいは複数のシグ ナルが交差し合流するような下流域に位置するのか決 定できる。2) 臨床由来の遺伝子を遺伝子破壊細胞に導 入することで、多型と突然変異を区別できる。3）機能 ドメインのみを破壊する際、GFP (Green fluorescent Protein) などの夕グマーカーを上下流のエクソンとフ レームが合うょうにノックインすれば、内在性遺伝子 産物の細胞内分布を可視化し、経時的に解析できる。 また、4）タグを利用した免疫沈降により、特異的な結 合タンパクを回収できプロテオーム解析に応用でき る。さらには、5) 薬剤候補、特に抗癌作用を示す化合 物の作用機序解明や化合物ライブラリーのヒト細胞ス クリーニング系として利用価值が高い。

今後は、標的遺伝子相同組み換えの誘導技術を含め た、より制御可能なゲノム改変技術の開発が期待され る。真核生物 RecA ホモログである Rad51 は、動物細 胞で相同組み換えに関与する十数種類の遺伝子産物 (Rad52 エピスタシスグループ) の中でも最も重要な働 きをする (West 2003)。Rad51を利用した組み換えの 人工的誘発法や、染色体レベルでの組み換えホットス ポットの同定と構造解明などが今後の課題として挙げ られる。

\section{4. おわりに}

これまでヒトとマウスのゲノムを比較することで、 どこが重要な領域かすばやく特定できた。およそ 7,500 万年も前に 2 つ種が分かれてから、変化して いない DNA 配列の存在する事実がその領域の重要性 を物語っている。今後はチンパンジーやニワトリ、イ 又を始め、ウシ、ブタ、ウマなどについてもゲノム解 読により、さらに多くの比較解析が可能となろう。分 子進化以外の研究として、ゲノム創薬、疾患原因遺伝 子の特定と治療・診断への応用、家畜の形質改良によ る経済的付加価值の向上など、どの目的をとってもゲ ノム情報を有効に活用することで遺伝子機能を生細胞 内で詳細に解明しなければならない。系統的な遺伝学 的解析ができる酵母やショウジョバエでは、変異クロ ーンを多く持っている研究室が圧倒的優位に研究を進 めることができた (Chasse と Dohlman 2004; Adams と Sekelsky 2002)。このような優位性を将来に得るため、 ヒトを含めた動物細胞株でも遺伝子破壊株の体系的な コレクション作成を開始すべき時期に来ている。

アミノ酸と発現調節領域の比較解析から、細胞周期 関連遺伝子は動物問において極めて高い保存性を見せ 
た。これは動物間における遺伝子機能の等価性を明瞭 に示す。ヒト・マウス・ラットやニワトリ以外でも、公 的な細胞バンク (JCRB など) にはサル、イヌ、ウシ、 ブ夕、ヤギ、ネコ、ウサギ、シカなどの株化細胞が存 在する。ニワトリDT40 細胞に匹敵するか、より有用 な家畜由来細胞が存在あるいは今後開発される可能性 は高い。ニワトリDT40 細胞では主にDNA 修復系遺 伝子 (Sonoda ら 1998) が、一方、ヒト HCT116 細胞で は細胞周期制御に関する遺伝子の変異株が作製されて きた。この様な相互に補完し合う状況は、動物ゲノム 情報の蓄積により他の動物種との間でも可能であろ う。体細胞での相同組み換え技術は、ヒト生殖系列細 胞での相同組み換えが倫理上困難であるため、今後も 重要であろう。家畜においては体細胞クローン技術の 利用により、形質に関わる候補遺伝子を破壊した体細 胞を作製後、そこからゲノム DNAを抽出し個体レべ ルでの解析も可能になるかもしれない。今後大量に供 給される動物ゲノム情報とそれを利用した遺伝子破壊 細胞における機能解析により、機能ゲノム学は新しい 展開を見せるだろう。

\section{謝辞}

本稿をまとめるにあたり、病理組織学的解析で助言 を頂いた小柳津直樹部長 (東京大学医科学研究所付属 病院検査部)にお礼申し上げます。

\section{引用文献}

Abdrakhmanov I, Lodygin D, Geroth P, Arakawa H, Law A, Plachy J, Korn B, Buerstedde JM. 2000. A large database of chicken bursal ESTs as a resource for the analysis of vertebrate gene function. Genome Research, 10: 2062-2069.

Adams MD, Sekelsky JJ. 2002. From sequence to phenotype: reverse genetics in Drosophila melanogaster. Nature Reviews Genetics, 3: 189-198.

Altschul SF, Madden TL, Schaffer AA, Zhang J, Zhang Z, Miller W, Lipman DJ. 1997. Gapped BLAST and PSI-BLAST: a new generation of protein database search programs. Nucleic Acids Research, 25: $3389-3402$.

Arakawa H, Lodging D, Buerstedde JM. 2001. Mutant lox vectors for selectable marker recycle and conditional knock-outs. BMC Biotechnology, 1: 7.

Arakawa H, Buerstedde JM. 2004. Immunoglobulin gene conversion: insights from bursal B cells and the DT40 cell line. Developmental Dynamics, 229: 458-464.

Baba TW, Giroir BP, Humphries EH. 1985. Cell lines derived from avian lymphomas exhibit two distinct phenotypes. Virology, 144: 139-151.

Bell SP, Dutta A. 2002. DNA replication in eukaryotic cells. Annual Review of Biochemistry, 71: 333-374.

Boardman PE, Sanz-Ezquerro J, Overton IM, Burt DW, Bosch E, Fong WT, Tickle C, Brown WR, Wilson SA, Hubbard SJ. 2002. A comprehensive collection of chicken cDNAs. Current Biology, 12: 1965-1969.

Boss JM. 1997. Regulation of transcription of MHC class II genes. Current Opinion in Immunology, 9: 107-113.

Brennecke J, Hipfner DR, Stark A, Russell RB, Cohen SM. 2003. bantam encodes a developmentally regulated microRNA that controls cell proliferation and regulates the proapoptotic gene hid in Drosophila. Cell, 113: $25-36$.

Brown JP, Wei W, Sedivy JM. 1997. Bypass of senescence after disruption of p21CIP1/WAF1 gene in normal diploid human fibroblasts. Science, 277 : $831-834$.

Brown WRA, Hubbard SJ, Tickle C, Wilson SA. 2003. The Chicken as a model for large-scale analysis of vertebrate gene function. Nature Reviews Genetics, 4: $87-98$.

Buck L, Axel R. 2001. A novel multigene family may encode odorant receptors: a molecular basis for odor recognition. Cell, 65: 175-187.

Buerstedde JM, Takeda S. 1991. Increased ratio of targeted to random integration after transfection of chicken B cell lines. Cell, 67: 179-188.

Buerstedde JM, Arakawa H, Watahiki A, Carninci PP, Hayashizaki YY, Korn B, Plachy J. 2002. The DT40 web site: sampling and connecting the genes of a B cell line. Nucleic Acids Research, 30: 230-231.

Bunz F, Dutriaux A, Lengauer C, Waldman T, Zhou S, Brown JP, Sedivy JM, Kinzler KW, Vogelstein B. 1998. Requirement for $\mathrm{p} 53$ and $\mathrm{p} 21$ to sustain $\mathrm{G} 2$ arrest after DNA damage. Science, 282: 1497-1501.

Caldwell RB, Kierzek AM, Arakawa H, Bezzubov Y, Zaim J, Fiedler P, Kutter S, Blagodatski A, Kostovska D, Koter M, Plachy J, Carninci P, Hayashizaki Y, Buerstedde JM. 2005. Full-length cDNAs from chicken bursal lymphocytes to facilitate gene function analysis. Genome Biology, 6: R6. 
Calin GA, Dumitru CD, Shimizu M, Bichi R, Zupo S, Noch E, Aldler H, Rattan S, Keating M, Rai K, Rassenti L, Kipps T, Negrini M, Bullrich F, Croce CM. 2002. Proceedings of the National Academy of Sciences of the United States of America, 99: 15524-15529.

Camon E, Magrane M, Barrell D, Binns D, Fleischmann W, Kersey P, Mulder N, Oinn T, Maslen J, Cox A, Apweiler R. 2003. The Gene Ontology Annotation (GOA) project: implementation of GO in SWISSPROT, TrEMBL, and InterPro. Genome Research, 13: $662-672$.

Castro A, Bernis C, Vigneron S, Labbe JC, Lorca T. 2005. The anaphase-promoting complex: a key factor in the regulation of cell cycle. Oncogene, 24: 314-325.

Chan TA, Hermeking H, Lengauer C, Kinzler KW, Vogelstein B. 1994. 14-3-3Sigma is required to prevent mitotic catastrophe after DNA damage. Nature, 401: 616-620.

Chan TA, Wang Z, Dang LH, Vogelstein B, Kinzler KW. 2002. Targeted inactivation of CTNNB1 reveals unexpected effects of beta-catenin mutation. Proceedings of the National Academy of Sciences of the United States of America, 99: 8265-8270.

Chasse SA, Dohlman HG. 2004. Identification of yeast pheromone pathway modulators by high-throughput agonist response profiling of a yeast gene knockout strain collection. Methods in Enzymology, 389: $399-409$.

Chong JP, Thommes P, Blow JJ. 1996. The role of $\mathrm{MCM} / \mathrm{P} 1$ proteins in the licensing of DNA replication. Trends in Biochemical Sciences, 21: $102-106$.

Deng C, Zhang P, Harper JW, Elledge SJ, Leder P. 1995. Mice lacking p21CIP1/WAF1 undergo normal development, but are defective in G1 checkpoint control. Cell, 82: 675-684.

Dhar SK*, Yoshida K*, Machida Y, Khaira P, Chaudhuri B, Wohlschlegel JA, Leffak M, Yates J, Dutta A. 2001. Replication from oriP of Epstein-Barr virus requires human ORC and is inhibited by geminin. Cell, 106: $287-296$. (*Co-first-authors)

Dyson N. 1998. The regulation of E2F by pRB-family proteins. Genes and Development, 12: 2245-2262.

Edwards JH. 1994. Comparative genome mapping in mammals. Current Opinion in Genetics and Development, 4: 861 - 867 .
Elbashir SM, Harborth J, Lendeckel W, Yalcin A, Weber K, Tuschl T. 2001. Duplexes of 21-nucleotide RNAs mediate RNA interference in cultured mammalian cells. Nature, 411: 494-498.

Fraser AG, Marcotte EM. 2004. A probabilistic view of gene function. Nature Genetics, 36: 559-564.

Grisart B, Coppieters W, Farnir F, Karim L, Ford C, Berzi P, Cambisano N, Mni M, Reid S, Simon P, Spelman R, Georges M, Snell R. 2002. Positional candidate cloning of a QTL in dairy cattle: identification of a missense mutation in the bovine DGAT1 gene with major effect on milk yield and composition. Genome Research, 12: 222-231.

Grobet L, Martin LJ, Poncelet D, Pirottin D, Brouwers B, Riquet J, Schoeberlein A, Dunner S, Menissier F, Massabanda J, Fries R, Hanset R, Georges M. 1997. A deletion in the bovine myostatin gene causes the double-muscled phenotype in cattle. Nature Genetics, 17: $71-74$

Hanson KD, Sedivy JM. 1995. Analysis of biological selections for high-efficiency gene targeting. Molecular and Cellular Biology, 15: 45-51.

Harbour JW, Luo RX, Dei Santi A, Postigo AA, Dean DC. 1999. Cdk phosphorylation triggers sequential intramolecular interactions that progressively block $\mathrm{Rb}$ functions as cells move through G1. Cell, 98: 859-869.

Hartwell LH. 1991. Twenty-five years of cell cycle genetics. Genetics, 129: 975-980.

Hubbard SJ, Grafham DV, Beattie KJ, Overton IM, McLaren SR, Croning MD, Boardman PE, Bonfield JK, Burnside J, Davies RM, Farrell ER, Francis MD, Griffiths-Jones S, Humphray SJ, Hyland C, Scott CE, Tang H, Taylor RG, Tickle C, Brown WR, Birney E, Rogers J, Wilson SA. 2004. Transcriptome analysis for the chicken based on 19,626 finished cDNA sequences and 485,337 expressed sequence tags. Genome Research, 15: 174-183.

Hunt T. 1989. Maturation promoting factor, cyclin and the control of M-phase. Current Opinion in Cell Biology, 1: $268-274$.

Huppi K, Martin SE, Caplen NJ. 2005. Defining and assaying RNAi in mammalian cells. Molecular Cell, 17: $1-10$.

International Chicken Genome Sequencing Consortium. 
2004. Sequence and comparative analysis of the chicken genome provide unique perspectives on vertebrate evolution. Nature, 432: 695-716.

International Chicken Polymorphism Map Consortium. 2004. A genetic variation map for chicken with 2.8 million single-nucleotide polymorphisms. Nature, 432: $717-722$.

International Human Genome Sequencing Consortium. 2001. Initial sequencing and analysis of the human genome. Nature, 409: 860-921.

International Human Genome Sequencing Consortium. 2004. Finishing the euchromatic sequence of the human genome. Nature, 431: 931 - 945.

Jaillon O, Aury JM, Brunet F, Petit JL, Stange-Thomann N, Mauceli E, Bouneau L, Fischer C, Ozouf-Costaz C, Bernot A, Nicaud S, Jaffe D, Fisher S, Lutfalla G, Dossat C, Segurens B, Dasilva C, Salanoubat M, Levy M, Boudet N, Castellano S, Anthouard V, Jubin C, Castelli V, Katinka M, Vacherie B, Biemont C, Skalli Z, Cattolico L, Poulain J, De Berardinis V, Cruaud C, Duprat S, Brottier P, Coutanceau JP, Gouzy J, Parra G, Lardier G, Chapple C, McKernan KJ, McEwan P, Bosak S, Kellis M, Volff JN, Guigo R, Zody MC, Mesirov J, Lindblad-Toh K, Birren B, Nusbaum C, Kahn D, Robinson-Rechavi M, Laudet V, Schachter V, Quetier F, Saurin W, Scarpelli C, Wincker P, Lander ES, Weissenbach J, Roest Crollius H. 2004. Genome duplication in the teleost fish Tetraodon nigroviridis reveals the early vertebrate proto-karyotype. Nature, 431: 946-957.

Jallepalli PV, Waizenegger IC, Bunz F, Langer S, Speicher MR, Peters JM, Kinzler KW, Vogelstein B, Lengauer C. 2001. Securin is required for chromosomal stability in human cells. Cell, 105: 445-457.

Kambadur R, Sharma M, Smith TP, Bass JJ. 1997. Mutations in myostatin (GDF8) in double-muscled Belgian Blue and Piedmontese cattle. Genome Research, 7: 910-916.

Kiriakidou M, Nelson PT, Kouranov A, Fitziev P, Bouyioukos C, Mourelatos Z, Hatzigeorgiou A. 2004. A combined computational-experimental approach predicts human microRNA targets. Genes and Development, 18: 1165-1178.

Knuppel R, Dietze P, Lehnberg W, Frech K, Wingender E. 1994. TRANSFAC retrieval program: a network model database of eukaryotic transcription regulating sequences and proteins. Journal of Computational Biology, 1: $191-198$.

Kuwabara T, Hsieh J, Nakashima K, Taira K, Gage FH. 2004. A small modulatory dsRNA specifies the fate of adult neural stem cells. Cell, 116: 779-793.

Maiorano D, Cuvier O, Danis E, Mechali M. 2005. MCM8 is an MCM2-7-related protein that functions as a DNA helicase during replication elongation and not initiation. Cell, 120: 315-328.

Mansour SL, Thomas KR, Capecchi MR. 1988. Disruption of the proto-oncogene int- 2 in mouse embryo-derived stem cells: a general strategy for targeting mutations to non-selectable genes. Nature, 336: 348-352.

Masui Y, Markert CL. 1971. Cytoplasmic control of nuclear behavior during meiotic maturation of frog oocytes. Journal of Experimental Zoology, 177: $129-145$.

Matzke MA, Birchler JA. 2005. RNAi-mediated pathways in the nucleus. Nature Reviews Genetics, 6: 24-35.

McPherron AC, Lee SJ. 1997. Double muscling in cattle due to mutations in the myostatin gene. Proceedings of the National Academy of Sciences of the United States of America, 94: 12457 - 12461.

McPherron AC, Lee SJ. 2002. Suppression of body fat accumulation in myostatin-deficient mice. Journal of Clinical Investigation, 109: 595-601.

Miller RD, Kwok PY. 2001. The birth and death of human single-nucleotide polymorphisms: new experimental evidence and implications for human history and medicine. Human Molecular Genetics, 10: 2195-2198.

Mouse Genome Sequencing Consortium. 2002. Initial sequencing and comparative analysis of the mouse genome. Nature, 420: 520-562.

Nurse P. 1994. Ordering S phase and M phase in the cell cycle. Cell, 79: 547-550.

O'Brien SJ, Menotti-Raymond M, Murphy WJ, Nash WG, Wienberg J, Stanyon R, Copeland NG, Jenkins NA, Womack JE, Marshall Graves JA. 1999. The promise of comparative genomics in mammals. Science, 286: $458-462,479-481$.

Page AM, Hieter P. 2005. The anaphase-promoting complex: new subunits and regulators. Annual Review of Biochemistry, 68: 583-609.

Pasquinelli AE, Ruvkun G. 2002. Control of 
developmental timing by microRNAs and their targets. Annual Review of Cell and Developmental Biology, 18: $495-513$.

Polyak K, Waldman T, He TC, Kinzler KW, Vogelstein B. 1996. Genetic determinants of p53-induced apoptosis and growth arrest. Genes and Development, 10: $1945-1952$.

Rajagopalan H, Jallepalli PV, Rago C, Velculescu VE, Kinzler KW, Vogelstein B, Lengauer C. 2004. Inactivation of hCDC 4 can cause chromosomal instability. Nature, 428: $77-81$.

Rat Genome Sequencing Project Consortium. 2004. Genome sequence of the Brown Norway rat yields insights into mammalian evolution. Nature, 428: $493-521$.

Reinhart BJ, Slack FJ, Basson M, Pasquinelli AE, Bettinger JC, Rougvie AE, Horvitz HR, Ruvkun G. 2000. The 21-nucleotide let-7 RNA regulates developmental timing in Caenorhabditis elegans. Nature, 403: 901-906.

Rhee I, Bachman KE, Park BH, Jair KW, Yen RW, Schuebel KE, Cui H, Feinberg AP, Lengauer C, Kinzler KW, Baylin SB, Vogelstein B. 2002. DNMT1 and DNMT3b cooperate to silence genes in human cancer cells. Nature, 416: 552-556.

Rocha JL, Pomp D, Van Vleck LD. 2002. QTL analysis in livestock. Methods in Molecular Biology, 195: 311-346.

Ross JS, Schenkein DP, Kashala O, Linette GP, Stec J, Symmans WF, Pusztai L, Hortobagyi GN. 2004. Pharmacogenomics. Advances in Anatomic Pathology 11: $211-220$.

Sedivy JM, Vogelstein B, Liber HL, Hendrickson EA, Rosmarin A. 1999. Gene targeting in human cells without isogenic DNA. Science, 283: 9a.

Shastry BS. 2002. SNP alleles in human disease and evolution. Journal of Human Genetics, 47: 561 - 566.

Sherr CJ. 1996. Cancer cell cycles. Science, 274: $1672-1677$.

Sherr CJ, Roberts JM. 1999. CDK inhibitors: positive and negative regulators of $\mathrm{G} 1$-phase progression. Genes and Development, 13: 1501-1512.

Smithies O, Gregg RG, Boggs SS, Koralewski MA, Kucherlapati RS. 1985. Insertion of DNA sequences into the human chromosomal beta-globin locus by homologous recombination. Nature, 317: 230-234.

Smithies O. 1993. Animal models of human genetic diseases. Trends in Genetics, 9: 112-116.

Sonoda E, Sasaki MS, Buerstedde JM, Bezzubova O, Shinohara A, Ogawa H, Takata M, Yamaguchi-Iwai Y, Takeda S. 1998. Rad51 deficient vertebrate cells accumulate chromosomal breaks prior to cell death. EMBO Journal, 17: 598-608.

Sontheimer EJ. 2005. Assembly and function of RNA silencing complexes. Nature Reviews Molecular Cell Biology, 6: $127-138$.

te Riele H, Maandag ER, Berns A. 1992. Highly efficient gene targeting in embryonic stem cells through homologous recombination with isogenic DNA constructs. Proceedings of the National Academy of Sciences of the United States of America, 89: 5128-5132.

The FANTOM Consortium and the RIKEN Genome Exploration Research Group Phase I \& II Team. 2002. Analysis of the mouse transcriptome based on functional annotation of 60,770 full-length cDNAs. Nature, 420: $563-573$.

The International Chimpanzee Chromosome 22 Consortium. 2004. DNA sequence and comparative analysis of chimpanzee chromosome 22. Nature, 429: $382-388$.

The International HapMap Consortium. 2003. The International HapMap Project. Nature, 426: 789-796.

Volkening M, Hoffmann I. 2005. Involvement of human MCM8 in prereplication complex assembly by recruiting hedc6 to chromatin. Molecular and Cellular Biology, 25: 1560-1568.

Venter JC, Smith HO, Hood L. 1996. A new strategy for genome sequencing. Nature, 381: 364-366.

Wahl MB, Caldwell RB, Kierzek AM, Arakawa H, Eyras E, Hubner N, Jung C, Soeldenwagner M, Cervelli M, Wang YD, Liebscher V, Buerstedde JM. 2004. Evaluation of the chicken transcriptome by SAGE of B cells and the DT40 cell line. BMC Genomics, 5: 98.

Waldman T, Kinzler KW, Vogelstein B. 1995. p21 is necessary for the p53-mediated G1 arrest in human cancer cells. Cancer Research, 55: 5187-5190.

Wang DG, Fan JB, Siao CJ, Berno A, Young P, Sapolsky R, Ghandour G, Perkins N, Winchester E, Spencer J, Kruglyak L, Stein L, Hsie L, Topaloglou T, Hubbell E, 
Robinson E, Mittmann M, Morris MS, Shen N, Kilburn D, Rioux J, Nusbaum C, Rozen S, Hudson TJ, Lipshutz R, Chee M, Lander ES. 1998. Large-scale identification, mapping, and genotyping of singlenucleotide polymorphisms in the human genome. Science, 280: 1077 - 1082.

Wang J, Takagaki Y, Manley JL. 1996. Targeted disruption of an essential vertebrate gene: ASF/SF2 is required for cell viability. Genes and Development, 10: $2588-2599$.

West SC. 2003. Molecular views of recombination proteins and their control. Nature Reviews Molecular Cell Biology, 4: 435-445.

Womack JE, Kata SR. 1995. Bovine genome mapping: evolutionary inference and the power of comparative genomics. Current Opinion in Genetics and Development, 5: 725-733.

Xie X, Lu J, Kulbokas EJ, Golub TR, Mootha V, LindbladToh K, Lander ES, Kellis M. 2005. Systematic discovery of regulatory motifs in human promoters and 3' UTRs by comparison of several mammals. Nature, 434: $338-345$.

Xu P, Vernooy MG, Guo M, Hay BA. 2003. The Drosophila microRNA Mir-14 suppresses cell death and is required for normal fat metabolism. Current Biology, 13: $790-795$.

Yoshida K, Kuo F, George EL, Sharpe AH, Dutta A. 2001. Requirement of CDC45 for postimplantation mouse development. Molecular and Cellular Biology, 21: 4598-4603.

Yoshida K, Inoue I. 2003. Conditional expression of MCM7 increases tumor growth without altering DNA replication activity. FEBS Letters, 553: 213-217.

Yoshida K, Oyaizu N, Dutta A, Inoue I. 2004. The destruction box of human Geminin is critical for proliferation and tumor growth in human colon cancer cells. Oncogene, 23: 58-70.

Yoshida K, Inoue I. 2004a. Regulation of Geminin and Cdt 1 expression by E2F transcription factors. Oncogene, 23: 3802-3812.

Yoshida K, Inoue I. 2004b. Expression of MCM10 and TopBP1 is regulated by cell proliferation and UV irradiation via the E2F transcription factor. Oncogene, 23: $6250-6260$.

Yoshida K. 2005a. Cell-cycle-dependent regulation of the human and mouse Tome-1 promoters. FEBS Letters 579: $1488-1492$.

Yoshida K. 2005b. Identification and characterization of human ZNF18 gene in silico. International Journal of Molecular Medicine, 15: 545-548.

Zhu W, Giangrande PH, Nevins JR. 2004. E2Fs link the control of $\mathrm{G} 1 / \mathrm{S}$ and $\mathrm{G} 2 / \mathrm{M}$ transcription. EMBO Journal, 23: $4615-4626$.

Zozulya S, Echeverri F, Nguyen T. 2001. The human olfactory receptor repertoire. Genome Biology, 2: RESEARCH0018. 